\title{
Australian Journal of Crop Science \\ Association mapping of agronomic traits of canola (Brassica napus L.) subject to heat stress under field conditions
}

\author{
Mizanur Rahaman', Sujan Mamidi², Mukhlesur Rahman*1 \\ ${ }^{1}$ Department of Plant Sciences, North Dakota State University, Fargo, ND 58102, USA \\ ${ }^{2}$ HudsonAlpha Institute for Biotechnology, Huntsville, AL, USA
}

*Corresponding author: md.m.rahman@ndsu.edu

\begin{abstract}
Brassica is a cool season crop and is susceptible to high temperatures. Developing heat stress tolerant varieties will help the crop to sustain under high temperature and can be used to extend the geographical range of cultivation. We have phenotyped 84 spring type Brassica napus accessions in field under natural heat conditions. Data on various agronomic traits were collected at the end of flowering to maturity stages. An association mapping study was performed to identify QTL associated with heat stress tolerant agronomic traits. A total of 37,269 single nucleotide polymorphism markers were used for this study. Multiple markers distributed on most of the chromosomes were identified. A total of 6,11, 7, 11 and 7 QTL were identified those explained 52.2\%, 71.8\%, 53.2\%, $73.5 \%$ and $61.0 \%$ of the total phenotypic variations for plant height, main raceme height, pods on main raceme, pod length, and sterile/aborted pod, respectively. Multiple candidate genes known to be involved in abiotic stress and abortion of different organs were identified in the vicinity of the QTL. For instance, B. napus BnaA03g09160D gene involved in programmed cell death and pollen sterility, BnaA05g33770D and BnaA05g33780D genes associated with pollen sterility and pod abortion were identified in the QTL regions.
\end{abstract}

Keywords: Brassica napus, heat stress, GBS, QTL, association mapping, field study.

\section{Introduction}

Rapeseed/canola (Brassica napus L.) is an amphidiploid $(2 \mathrm{n}=4 \mathrm{x}=38, \mathrm{AACC})$ that originated from the hybridization of two diploid species, Brassica rapa $(2 \mathrm{n}=2 \mathrm{x}=20$, AA) and $B$. oleracea $(2 \mathrm{n}=2 \mathrm{x}=18, \mathrm{CC})$ (U, 1935; Raymer, 2002). The genome size of this crop is about $1,130 \mathrm{Mb}$. The $\mathrm{C}$ genome is larger than the A genome which is consistent to the genome sizes of B. oleracea and B. rapa, respectively (Chalhoub et al., 2014). Rapeseed ranks second in the world as an oilproducing crop next to soybean (Foreign Agricultural Service, USDA, October 2016). Within the USA, about $84 \%$ of canola is produced in North Dakota with a market value of about \$384 million/year (5-year average from 2011-2015; USDA-NASS, January 2016).

Although rapeseed is a valuable oilseed crop, the production of this crop is hampered due to different biotic and abiotic stresses such as disease, pests, heat, drought, cold stress etc. High temperature creates a lethal environment for the growth and development of plants, and produces different types of metabolites, toxins and alters the hormonal activity, which creates abnormal phenotypes. Plants are able to cope with the stress conditions by reducing the growth and development, yield, and by changing morphological, physiological, biochemical, and molecular properties (Bita and Gerats, 2013). Temperature increase of $3-4^{\circ} \mathrm{C}$ from its normal range during reproductive stages, even for a short duration, could cause 15-35\% yield loss (Ortiz et al., 2008). Generally, the suitable temperature for spring canola production is about $15-20^{\circ} \mathrm{C}$, but the temperature over $27^{\circ} \mathrm{C}$ causes pollen sterility and pod abortion (Morrison, 1993; Angadi et al., 2000; Nuttal et al., 1992). Rapeseed production under increased temperature from $28^{\circ} \mathrm{C}$ to $35^{\circ} \mathrm{C}$ could reduce the seed yield by about $54 \%$ to $87 \%$ (Gan et al., 2004). It has been estimated that $1^{\circ} \mathrm{C}$ temperature increase from the suitable range of crop growth and development in July can cause $10 \%$ yield reduction of canola in Saskatchewan, Canada (Nuttal et al., 1992). Heat stress during pre-anthesis stage reduces pollen fertility, whereas post anthesis heat decreases the female fertility of B. juncea (Rao et al., 1992). The generative stage of crop development is highly sensitive to heat stress (Bita and Gerats, 2013). This sensitivity increases the flower abortion, pollen sterility, tapetum degeneration (Oshino et al. 2007; Endo et al., 2009), and reduces the pod development, seed set, assimilatory capacity and productivity (Barnabás et al., 2008), shoot and root growth (Vollenweider and Günthardt-Goerg, 2005), seed yield (Ahuja et al., 2010; Mittler and Blumwald, 2010). The reason of these changes are due to reduced photosynthesis (Zhang et al., 2006), radiation use efficiency (Hasanuzzaman et al., 2013), increased plant respiration (Reynolds et al., 2007), Reactive Oxygen Species (ROS) production (Dat et al., 1998; Gong et al., 1998; Volkov et al., 2006), lipid peroxidation, protein degradation (Savchenko et al., 2002), hyperfluidization and disruption of plant cell membranes (Horváth et al., 1998; Sangwan et al., 2002), metabolic imbalance (Vierling, 1991; Dat et al., 1998; Gong et al., 1998; Volkov et al., 2006), disrupted biosynthesis and compartmentalization of metabolites (Maestri et al., 2002), genomic rearrangements (Ivashuta et al., 2002; Steward et al., 2002), demethylation of transposons (Bennetzen, 2000) and so on. 
Heat stress tolerance in plants is a multigenic character. The specific role of the genes in heat stress tolerance is not yet identified in crops (Frank et al., 2009). Due to the complexity of physiological traits and their interaction with the environment the short-term solution for heat stress tolerance is quiet unknown to the scientific community (Shao et al., 2007).

Association mapping (AM) is based on the linkage disequilibrium and utilizes ancestral recombinations and natural genetic diversity within a population to quantify the quantitative traits (Geiringer, 1944; Lewontin and Kojima, 1960), where linkage disequilibrium is a non-random association of alleles at two loci. It is an alternative method to discover genetic factors using biparental crosses, and has a higher mapping resolution within a large number of unrelated individuals. This helps to identify common genetic variants, which control a common phenotype (Risch, 2000). It is relatively new and promising genetic method for complex trait dissection of plants (Zhu et al., 2008), and for QTL identification (Yu et al., 2006). It uses a sample of accessions from the germplasm collections, which have accumulated many rounds of recombination events. This method has been used in many crop and animal species to identify marker-trait associations. As heat stress is a complex trait, AM would be a good approach to locate the genomic regions associated with heat stress affected phenotypes. In the light of these facts, this research scheme has been taken to identify the genomic regions associated with the heat stress traits in a collection of spring type B. napus accessions under field conditions.

\section{Results}

\section{Phenotyping of plant materials}

The phenotypic variation of the five traits were variable in field conditions during the flowering to maturity stages. Of the genotypes, raceme height varied between $15.5 \mathrm{~cm}$ and $61.1 \mathrm{~cm}$, and pod/raceme had a range of 13.0 to 52.6. The Shapiro-Wilk test of normality indicated that the population for raceme height $(p<0.198)$ and pod/raceme $(p<0.150)$ are normally distributed (Table 1, Fig. 1). The plant height ranged from $68 \mathrm{~cm}$ to $134 \mathrm{~cm}$, pod length ranged between $4.24 \mathrm{~cm}$ amd $8.21 \mathrm{~cm}$, and sterile/aborted pod varied between $1.68 \%$ and $30.1 \%$. The Shapiro-Wilk test of normality of plant height $(p<0.008)$, pod length $(p<0.006)$, and sterile/aborted pod $(p<0.0004)$ indicated non-normality of the distribution (Table 1, Fig. 1).

\section{Population structure, PCA and relatedness}

A total of 37,269 SNP markers were used after removing for minor allele frequency of $5 \%$. About $20.6 \%$ heterozygous loci were present in these samples. Principal component analysis has grouped the population into three continuous clusters using the first two principal components (Fig. 2).

\section{Association mapping (AM)}

Six regression models were used to test the phenotypic variation associated with the SNPs. Out of the six models tested in the analysis, the model with $\mathrm{PC}_{17}+$ kinship was found as the best models for plant height, and pod abortion. The model $\mathrm{PC}_{17}$ was the best model for the main raceme height and number of pods on main raceme, whereas $\mathrm{PC}_{3}$ was the best model for pod length.

During the marker trait association, three markers were found significant for plant height at 0.01 percentile tail of empirical distribution ( $p \leq 2.99 \mathrm{E}-05$, Table 2, Fig. 3). Among these three markers, two were located on chromosomes C03 (0.5 Mbp) and one on C08 (32.368 Mbp). Additionally, 35 markers were found significant at 0.01 percentile tail of the empirical distribution $(p \leq 5.18 \mathrm{E}-04$; Supplementary table S3). These markers were found on multiple chromosomes. A stepwise regression with these markers identified six significant QTL regions (Table 3, Fig. 4) which together explained $52.2 \%$ of the total phenotypic variation. The identified candidate genes associated with this trait include kinase family protein that plays an important role in plant growth and development, iron regulated 2 protein associated with iron (Fe) availability for plants, which is an essential mineral element for plant growth and development. Ethyleneresponsive nuclear protein (ERT2), that regulates plant growth and development through cell division, and gibberellin 2-oxidase involved in plant growth and development, were also identified in the QTL regions (Supplementary table S4).

Five markers were significantly associated with raceme height at 0.01 percentile ( $\mathrm{p} \leq 8.39 \mathrm{E}-05$; Table 2; Fig. 3). These significant markers were located on chromosome A02 (1.13 Mbp), A10 (1.216 Mbp) and C01 (15.6 and 26.1Mbp). Thirty-one additional markers were found significant at 0.1 percentile tail of the distribution $(p \leq 7.84 \mathrm{E}-04$, Supplementary table S3). Eleven QTL regions were identified through stepwise regression. These 11 QTL together explained $71.8 \%$ of phenotypic variation and were located on chromosomes A02, A03, A10, C01, C05, C07, and C08 (Table 3, Fig. 4). Many candidate genes such as plant calmodulin-binding protein that is associated with $\mathrm{Ca} 2+$ binding, plant growth and development, indole acetic acidinduced protein 10 that enhances plant growth under drought stress condition, protein kinase family protein that is involved in stem elongation and vascular development, ACC oxidase 1 that favors plant growth and lowering stress susceptibility were identified (Supplementary table S4).

For number of pods on main raceme, five markers were identified significant at 0.01 percentile $(p \leq 2.98 \mathrm{E}-04$, Table 2, Fig. 3). One of these markers was located on chromosome A09 (26.3 Mbp). Besides these markers, 20 more markers were found significant at 0.1 percentile tail of the empirical distribution ( $p \leq 9.86 \mathrm{E}-04$, Supplementary table S3). Further, seven major QTL were identified through stepwise regression, which together explained $53.2 \%$ of phenotypic variation (Table 3, Fig. 4). Among them, four QTL were located on chromosomes A09, C01, C03 and C09. Multiple candidate genes such as adenine nucleotide alpha hydrolaseslike superfamily protein known to be involved in male sterility, protein kinase superfamily protein involved in pollen abortion, pyruvate kinase family protein associated with early embryo abortion, proline-rich family protein associated with flower and pod development are present in the QTL regions (Supplementary table S4).

Four markers associated with pod length at 0.01 percentile tail ( $p \leq 3.72 \mathrm{E}-05$, Table 2, Fig. 3) were located on chromosome C02 (33.4 Mbp), C03 (58.6 Mbp) and C09 (43.4 Mbp). Another 34 markers were found significant at 0.1 percentile tail of the empirical distribution $(p \leq 9.87 \mathrm{E}-05$, Supplementary table S3). A total of $73.5 \%$ phenotyping variation was explained by 11 major QTL (Table 3, Fig. 4). These QTL were located on A03, A05, A09, A10, C01, C03, $\mathrm{C} 07$, and C09 chromosomes. Multiple genes such as cellulose synthesis like A14 known to be involved in the young seedpod development, plant self-incompatibility protein S1 family that severely reduce pollen coats and cause male sterility, glutamine synthetase 1:4 which is involved in 
Table 1. Variation in different agronomic traits of B. napus under natural heat stress in field condition.

\begin{tabular}{lllllll}
\hline Traits & Average & $\begin{array}{l}\text { Standard } \\
\text { deviation }\end{array}$ & Maximum & Minimum & $\begin{array}{l}\text { p-value of } \\
\text { Shapiro-Wilk } \\
\text { normality test }\end{array}$ & $\begin{array}{l}\text { Coefficient of } \\
\text { Variation }\end{array}$ \\
\hline Plant height $(\mathrm{cm})$ & 96.9 & 12.6 & 134 & 68.0 & 0.008 & 13.0031 \\
Raceme height $(\mathrm{cm})$ & 39.9 & 8.64 & 61.1 & 15.5 & 0.198 & 21.6541 \\
Pod/raceme & 30.2 & 8.15 & 52.6 & 13.0 & 0.150 & 26.9868 \\
Pod length $(\mathrm{cm})$ & 6.62 & 0.8 & 8.21 & 4.27 & 0.006 & 5.0846 \\
Sterile/aborted pod $(\%)$ & 9.74 & 5.54 & 30.1 & 1.68 & 0.0004 & 56.8789 \\
\hline
\end{tabular}
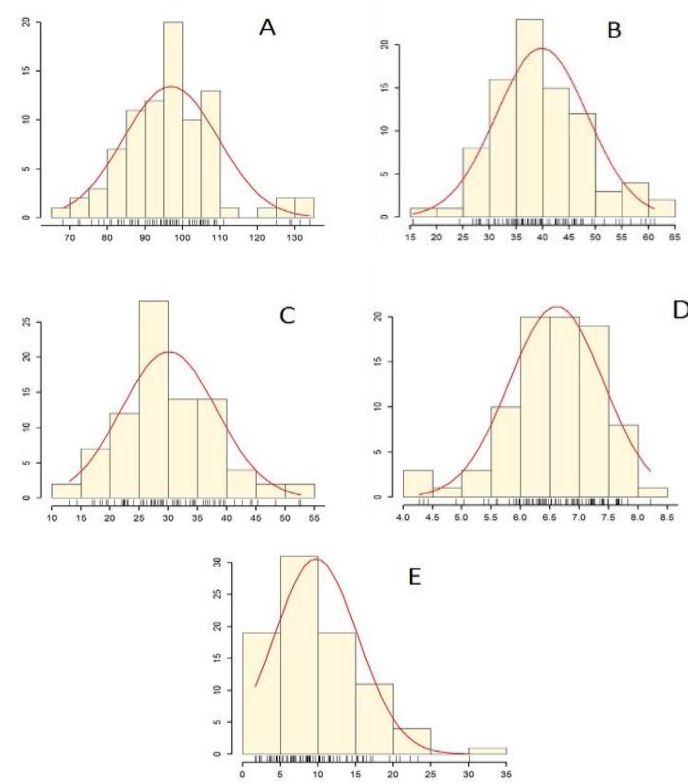

Fig 1. Phenotypic distribution of five different traits under field condition, (A) plant height $(\mathrm{cm}),(B)$ raceme height $(\mathrm{cm}),(C)$ number of pods on main raceme, (D) pod length $(\mathrm{cm})$, and (E) flower and pod abortion.

Table 2. Significant markers at 0.01 percentile associated with five different agronomic traits under natural heat stress condition.

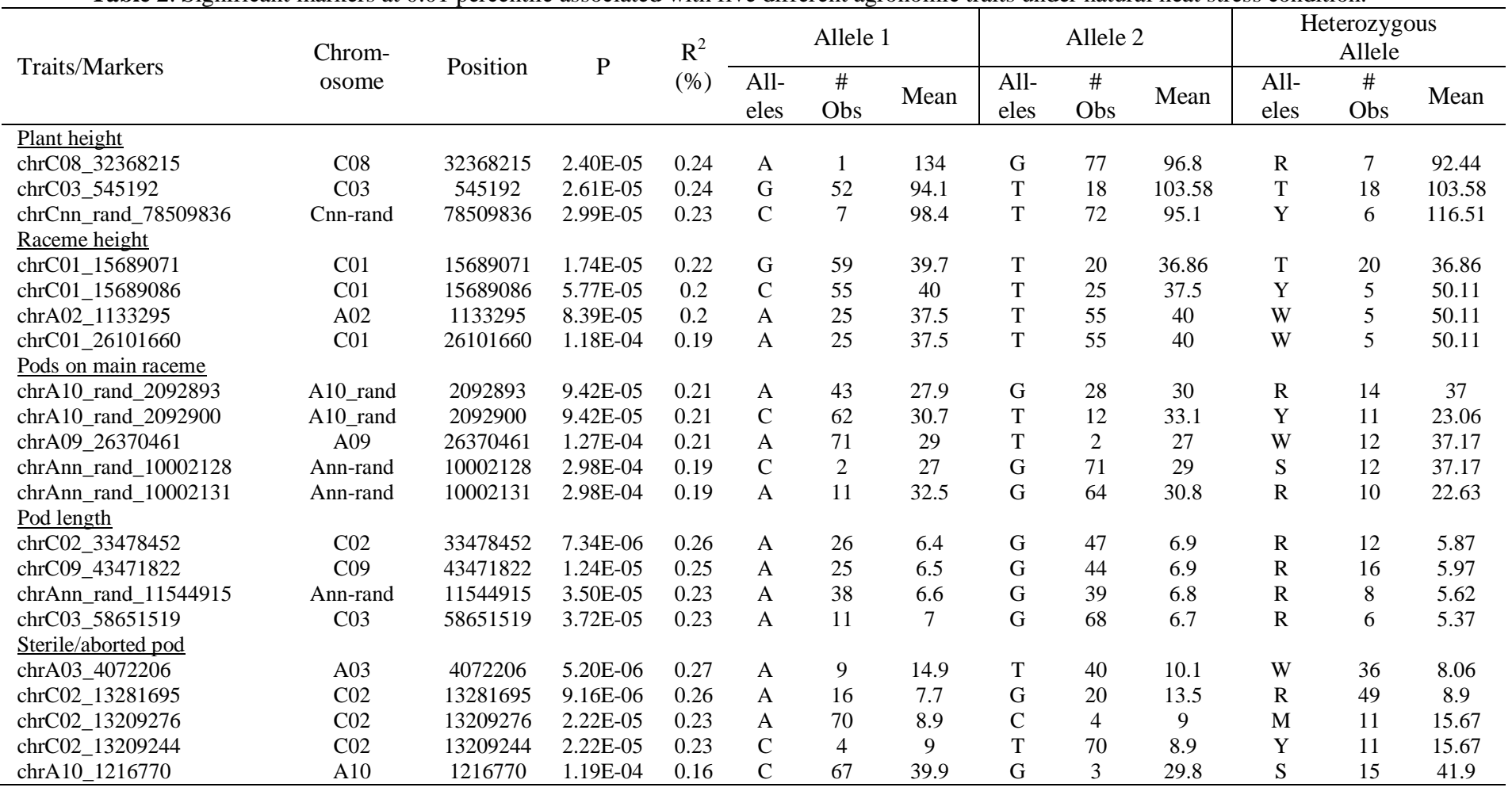




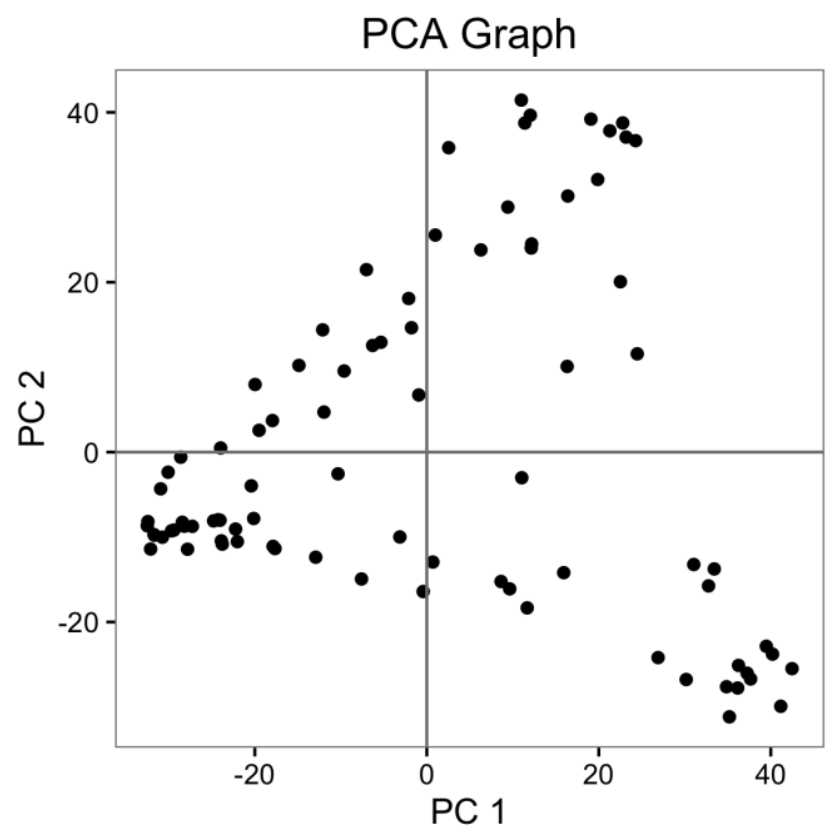

Fig 2. $\mathrm{PC}$ graph of the first two principal components using 37,269 polymorphic SNPs. The $\mathrm{X}$-axis is representing PC1 and $\mathrm{Y}$-axis is PC2. This graph explains the similarities among the germplasm accessions and the overall population structure.

Table 3. Significant Markers and QTL associated with total phenotypic variation of five different traits.

\begin{tabular}{|c|c|c|c|c|c|}
\hline Trait & $\begin{array}{c}\text { \# of significant } \\
\text { markers }\end{array}$ & \# of QTL & Chromosomes & Position (Mbp) & \%Phenotypic variation \\
\hline \multirow{6}{*}{ Plant height } & 38 & 6 & A01 & 2.76 & 52.2 \\
\hline & & & $\mathrm{C} 03$ & 0.54 & \\
\hline & & & $\mathrm{C} 06$ & 5.17 & \\
\hline & & & $\mathrm{C} 07$ & 38.5 & \\
\hline & & & $\mathrm{C} 07$ & 6.80 & \\
\hline & & & $\mathrm{C} 08$ & 32.3 & \\
\hline \multirow{11}{*}{ Main raceme height } & 36 & 11 & A02 & 1.13 & 71.8 \\
\hline & & & A03 & 19.9 & \\
\hline & & & A10 & 1.21 & \\
\hline & & & $\mathrm{C} 01$ & 15.6 & \\
\hline & & & $\mathrm{C} 01$ & 26.1 & \\
\hline & & & $\mathrm{C} 05$ & 39.3 & \\
\hline & & & $\mathrm{C} 05$ & 1.57 & \\
\hline & & & $\mathrm{C} 07$ & 35.3 & \\
\hline & & & C08 & 16.8 & \\
\hline & & & Cnn_rand & 67.4 & \\
\hline & & & Cnn_rand & 22.2 & \\
\hline \multirow[t]{7}{*}{ Pods on main raceme } & 25 & 7 & A09 & 26.3 & 53.2 \\
\hline & & & $\mathrm{C} 01$ & 3.05 & \\
\hline & & & $\mathrm{C} 01$ & 9.23 & \\
\hline & & & $\mathrm{C} 03$ & 8.00 & \\
\hline & & & C09 & 3.59 & \\
\hline & & & A10_rand & 2.09 & \\
\hline & & & Ann_rand & 10.0 & \\
\hline \multirow[t]{11}{*}{ Pod length } & 38 & 11 & A03 & 4.12 & 73.5 \\
\hline & & & A05 & 20.3 & \\
\hline & & & A09 & 32.4 & \\
\hline & & & A10 & 16.4 & \\
\hline & & & $\mathrm{C} 01$ & 14.8 & \\
\hline & & & $\mathrm{C} 01$ & 16.9 & \\
\hline & & & $\mathrm{C} 03$ & 1.38 & \\
\hline & & & $\mathrm{C} 03$ & 12.3 & \\
\hline & & & $\mathrm{C} 07$ & 40.1 & \\
\hline & & & C09 & 43.4 & \\
\hline & & & $\mathrm{C} 02$ rand & 3.64 & \\
\hline \multirow[t]{7}{*}{ Sterile/aborted pod } & 35 & 7 & A05 & 22.8 & 61.0 \\
\hline & & & A07 & 1.11 & \\
\hline & & & $\mathrm{C} 02$ & 13.2 & \\
\hline & & & $\mathrm{C} 04$ & 5.45 & \\
\hline & & & $\mathrm{C} 04$ & 5.46 & \\
\hline & & & C05 & 22.9 & \\
\hline & & & C04_rand & 0.98 & \\
\hline
\end{tabular}




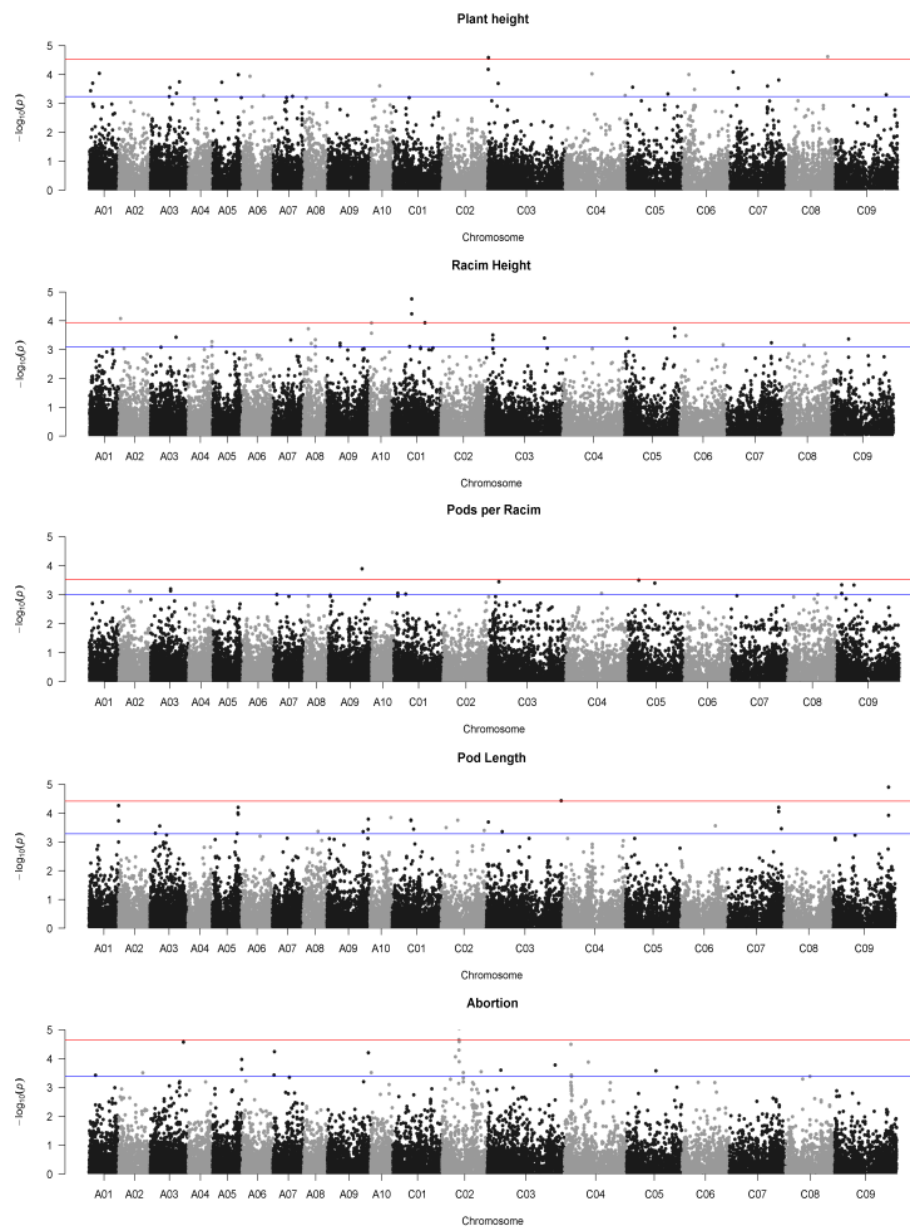

Fig 3. Manhattan plots showing p values across 19 chromosomes of B. napus for SNP markers associated with five different traits.

B-deficiency and pod development were present in the QTL region (Supplementary table S4).

Variation in sterile/aborted pod was associated with four significant markers at 0.01 percentile $(p \leq 5.20 \mathrm{E}-06$, Table 2 , Fig. 3). These markers were located on chromosome A03 (4.07 Mbp) and C02 (13.20 Mbp). Further 31 markers were identified with significance at 0.1 percentile tail of the empirical distribution $(p \leq 2.57 \mathrm{E}-05$, Supplementary table S3). A stepwise regression was performed, and 7 QTL regions were identified that explained $61.0 \%$ of phenotypic variation of sterile/aborted pod (Table 3, Fig. 4). Many candidate genes known to be involved in organ abortion were also identified. These genes included heat shock proteins, genes associated with male sterility, embryo abortion, pollen abortion, and reduced flowering fertility (Supplementary table S4).

\section{Discussion}

Rapeseed/canola is a cool season crop and is sensitive to heat stress (Morrison, 1993). Increasing temperatures and heat stress are a growing concern for canola production. Therefore improvement of the crop against heat stress traits may help the adaptation and expansion of the geographical range of cultivation of this crop. To achieve this, a genome-wide association study was conducted to identify significant markers closely associated with heat stress effected traits, that can be helpful for marker assisted selection. The germplasm accessions flowered within 40-60 days of planting were considered as spring type. These accessions were exposed to natural heat stress in the field during the reproductive stage. Many studies on heat stress under controlled conditions are available, however very limited studies on heat stress affected traits of canola under field conditions are available. The germplasm used in this study are originated/obtained from 13 countries (3 continents), and have relatively higher genetic diversity. These genotypes represent the most available spring type diversity in our germplasm collection. This diversity will generate a better mapping resolution and help to identify QTL regions that can be used for marker assisted selection (MAS). These genotypes respond differently to heat stress and lead to a higher phenotypic variability.

We studied plant height, main raceme height, number of pods on main raceme, pod length, and sterile/aborted pod of canola under field conditions. The phenotypic data is from a single year field study. This is similar to Hwang et al. (2014), who conducted a genome-wide association study of seed protein and oil content in soybean with one-year field trial. Zegeye et al. (2014) conducted association mapping on seedling and adult plant resistance to stripe rust in synthetic hexaploid wheat using single year data. Bellucci et al. (2015) conducted a single year field trial for association mapping in Scandinavian winter wheat for seed yield, plant height, and 


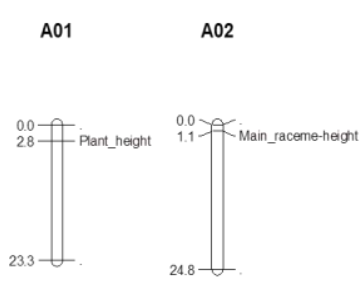

A03

A05

A07

A09

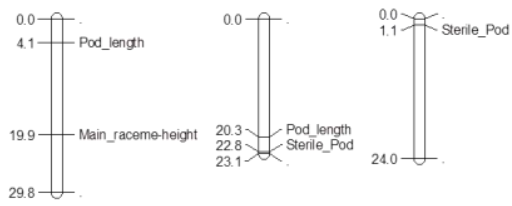

A10

A10_rand

Ann_rand
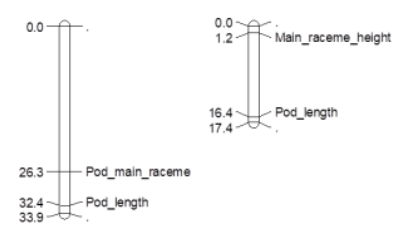

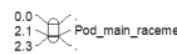

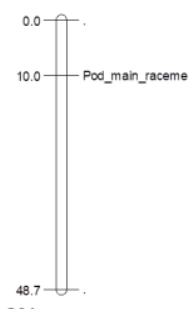

Co1

C02

C03

C04
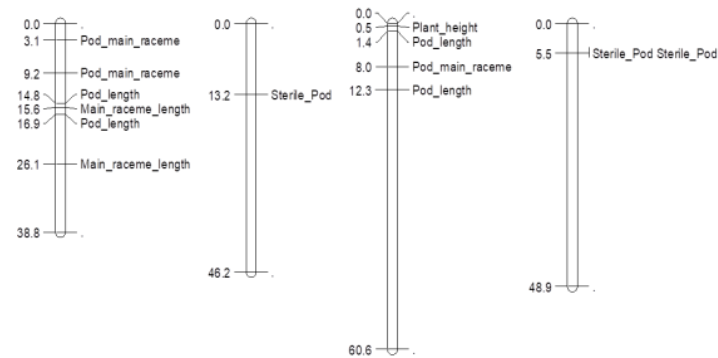

C05

Co

Co7

Cos
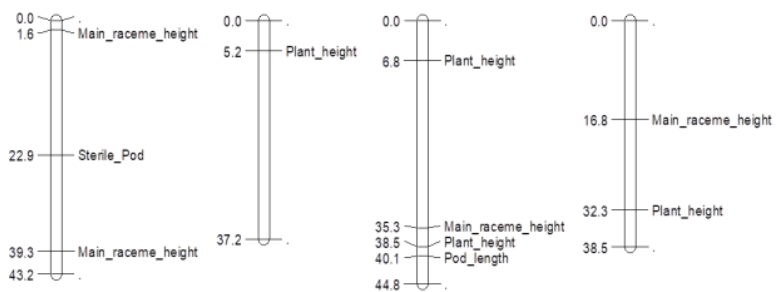

$\cos$

C02_rand

Cnn_rand

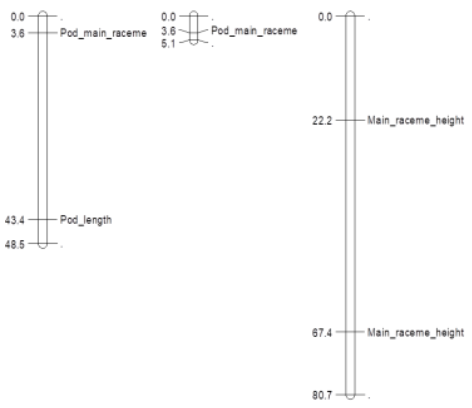

Fig 4. The QTL positions of plant height, main raceme height, pods on main raceme, pod length, and sterile/aborted pods located on different chromosomes of B. napus. 
traits important for second-generation bioethanol production. Even though studies based on multiple years might be beneficial for QTL identification that could effectively be used for MAS. However, the drawback would be availability of heat stress during reproductive stage in multiple years. Since the intended application is minimizing the generation advancement effort, by using marker assisted selection, data from one year should suffice.

The plant height and main raceme height varied significantly among the genotypes. Heat stress negatively affects the plant height and inflorescence height through reducing photosynthesis, which is one of the most heat sensitive physiological processes in plants (Yamamoto et al., 2008). Heat stress causes significant pod sterility and pod abortion (Morrison, 1993). Variable flower and pod abortion were also observed in our study. Variability of pod abortion due to heat stress is also reported in other crops such as tomato (Levy et al., 1978; Abdul-Baki, 1991), Capsicum annum L. (Rylski, 1986; Erickson and Markhart, 2002), bean (Konsens et al., 1991), cowpea (Craufurd et al., 1998), pea (Wery and Tardieu, 1997), and cotton (Reddy et al., 1992). Heat stress affects the tapetum layer of pollen and reduces the nutrition supply, especially during microspore development. This shortage of nutrient supply affects the male gametogenesis, and hamper the formation of microspore cells and ultimately causes pod abortion (Ma et al., 2005).

Multiple genes, and biochemical and metabolic pathways govern the heat stress tolerance in plants. For example, antioxidant activity, membrane lipid unsaturation, gene expression and protein translation, stability of protein, and accumulation of compatible solutes play a significant role in heat stress tolerance (Kaya et al., 2001). Heat stress has a significant role in growth, development and reproduction of Brassica (Morrison, 1993; Angadi et al., 2000; Nuttal et al., 1992).

In this study, a genome-wide association study (GWAS) was conducted to identify significant markers associated with the five agronomic traits that are known to be affected by heat-stress. GWAS helps to identify candidate genes for each trait of interest in a population. It is also a powerful tool to identify QTL associated with various traits of crop species (Huang et al., 2012). The phenotypic variation of many complex traits is influenced by multiple QTL and association mapping helps to identify molecular markers that are closely linked to the QTL or genes controlling the traits ( $\mathrm{Li}$ et al., 2011). We used single nucleotide polymorphism (SNP) markers for our association mapping study. SNPs are frequently used markers, which contribute the majority of genotyping in different crop species including B. napus (Trick et al., 2009).

About 37,000 SNPs were used in this study. The missing data of the SNPs was imputed to increase the map resolution of the study and to map the causal variant of the analysis. To protect from spurious marker-trait associations (Price et al., 2010), we tested different regression models that include structure and/or relatedness. Initially, a large number of significant markers were identified associated with heat stress traits. Further, bootstrapping identified only a few QTL significantly associated to heat stress affected traits (Mamidi et al., 2014). This is similar to earlier research, where several studies identified QTL associated with heat stress in various crops such as rice (Ye et al., 2012), cowpea (Vigna unguiculata) (Lucas et al., 2013), and tomato (Grilli et al., 2007) with a phenotypic variation between 2 and 20\%. The significant marker was selected around $100 \mathrm{kbp}$ of each side of the major QTL due to the lower LD of the studied canola accessions (Monika et al., Unpublished).
Plant height is an important trait of canola affected by heat stress. Heat stress affects the photosynthesis (Crafts-Brandner and Salvucci, 2002) and produce Reactive Oxygen Species (ROS) (Hasanuzzaman et al., 2013) which severely reduces plant growth and development. Plants accumulate protein and osmolytes under heat stress, which help to continue photosynthesis by enhancing the activities of many antioxidants like superoxide dismutase (SOD), catalase (CAT) and peroxidise (POD), and by scavenging the harmful ROS (Warich et al., 2012). In our study, the combined phenotypic variation of plant height due to the major QTL was about 53\%. The heavy metal transport/detoxification superfamily protein gene was found in chromosome $\mathrm{C} 03$ which was only $4 \mathrm{kbp}$ apart from the major QTL at $545 \mathrm{kbp}$. This gene is associated with plant growth and development and helps to sustain growth under abiotic stress conditions (Hall 2002). Many other genes were found associated with heat stress such as gibberellin 2-oxidase 8 which regulates plant growth (Lo et al., 2008), ethylene-regulated nuclear protein (ERT2), which regulates plant growth and development through cell elongation and cell division (Sakai et al., 1998), ABC-2 type transporter family protein is involved in plant growth, development and response to abiotic stresses (Kang et al., 2011). Other genes associated with plant growth and development such as $\mathrm{C} 2 \mathrm{H} 2$-like zinc finger protein (Chrispeels et al., 2000), iron regulated 2 (Yang et al., 2013), and core-2/I-branching beta-1,6-Nacetylglucosaminyltransferase family protein (Lin et al., 2015) were also identified.

Raceme height is correlated with the plant height that is ultimately associated with yield of canola. GWAS revealed 36 significant SNP markers and eleven QTL on chromosomes A02, A03, A10, C01, C05, C07 and C08. Many candidate genes were identified that are associated with raceme height and are involved in different physiological process. Of these candidate genes, Core-2/Ibranching beta-1,6-N-acetylglucosaminyltransferase family proteins involved in plant development (Lin et al., 2015), plant calmodulin-binding protein is associated with $\mathrm{Ca} 2+$ binding and plant growth (Ranty et al., 2006), indoleacetic acid-induced protein 10 which enhances plant growth under drought stress condition (Yasin et al., 2006), protein kinase family protein involved in stem elongation and vascular development (Matschi et al., 2013), auxin response factor 1 regulates plant growth and development (Li et al., 2016), mitogen-activated protein kinase acts as signal transporter for cell division and plant growth (Sinha et al., 2011), AP2/B3like transcriptional factor family protein is involved in plant growth (Song et al., 2013), ACC oxidase 1 is involved in plant growth and lowering stress susceptibility (Van de Poel and Van Der Straeten, 2014).

Number of pods on main raceme depends on the pod development and rate of aborted pods. Pollination and fertilization is the prerequisite for the pod development of crops. Heat stress affects the pollination of Brassica through the desiccation of pollen and reduction in the pollen receptivity of the stigma (Rao et al., 1992). Many genes are involved in the variation of number of pods per plant. We have identified seven significant QTL that explained 53.2\% of total phenotypic variation. One significant marker on chromosome $\mathrm{C} 03$ at $8.00 \mathrm{Mbp}$ is located in Brassica gene BnaC03g15870D that contain protein kinase superfamily protein, which is involved in pollen abortion of crops (Radchuk et al., 2006). Many other candidate genes were identified that are associated with the variation of number of pods per plants. Among the candidate genes, basic helixloop-helix (bHLH) DNA-binding superfamily protein that is 
involved in the development and dehiscence of seed and pod (Hudson and Hudson, 2015), protein kinase superfamily protein is involved in pollen abortion (Radchuk et al., 2006), pyruvate kinase family protein associated with early embryo abortion of flower (Zhang et al., 2014), ARM repeat superfamily protein is involved in self-incompatibility and reduction of pod number (Sharma and Pandey, 2016), chaperone DNAJ-domain superfamily protein is involved in male sterility (Yang et al., 2009), DNAJ heat shock Nterminal domain-containing protein that increases tolerance to heat and prevents fruit drop (Zhao et al., 2015), prolinerich family protein associated with flower and pod development (Giorno et al., 2013), adenine nucleotide alpha hydrolases-like superfamily protein is involved in male sterility (Mok and Mok, 2001), homeodomain-like protein regulates anther dehiscence (Wilson et al., 2011), cytochrome P450 is involved in the pollen tube development and fertilization (Zhao et al., 2015), pyruvate kinase family protein found associated with early embryo abortion (Zhang et al., 2014).

Pod length is one of the indicators of seed yield in Brassica. Pod length is also affected by heat stress. High temperature reduces the photosynthetic capacity (CraftsBrandner and Salvucci, 2002) and increase pollen abortion (Zhang et al., 2014), which in turn affects the growth and development of pod. We have identified 11 QTL associated with pod length in relation to heat stress. The QTL together explained a phenotypic variation of $73.5 \%$. One marker, chrA03 4124353, located on chromosome A3, is only $1 \mathrm{~kb}$ away from Brassica gene BnaA03g09160D (Cysteine/Histidine-rich $\mathrm{C} 1$ domain family protein). This gene is involved in tapetal development, programmed cell death (PCD) and pollen grain sterility (Zhang et al., 2014). Many other genes such as 2-oxoglutarate (2OG) and Fe(II)dependent oxygenase superfamily protein (Leisner et al., 2014), cysteine/histidine-rich C1 domain family protein (Zhang et al., 2014), heat shock protein 18.2 (Kim and Hong, 2001), zinc finger (C3HC4-type RING finger) family protein (Wu et al., 2014), cellulose synthase like A14 (Park et al., 2013), homeodomain-like superfamily protein (Wilson et al., 2011), syntaxin of plants 71 (Sharma and Nayyar, 2014), cellulose synthase 5 (Park et al., 2013), plant selfincompatibility protein S1 family (Samuel et al., 2009), cytochrome P450 (Zhao et al., 2015), ubiquitin family protein (Mazzucotelli et al., 2006), malectin/receptor-like protein kinase family protein (Matschi et al., 2013), glutamine synthetase 1;4 (Bargaz et al., 2015), auxin response factor 19 ( $\mathrm{Li}$ et al., 2016), AGAMOUS-like 24 (Yu et al., 2002), P450 reductase 1 (Bak et al., 2011) were also identified associated with the cytoplasmic male sterility, pollen tube and pollen coat development, boron deficiency, and seed pod development.

Sterile/aborted pod is significantly affected by heat stress, and causes significant yield loss of Brassica. Thirty-five SNPs were identified associated with sterile/aborted pod on different chromosomes. Stepwise regression identified seven significant QTL located on chromosome A05, A07, C02, $\mathrm{C} 04$, and $\mathrm{C} 05$. The markers chrC04_5456736, and ChrC04_rand_988002 were 4kb apart from Brassica gene BnaC04g07360D and BnaC04g01250D, respectively. Two other markers chrA05_22801086 and chrA05_22801086 were also found 5 and $6 \mathrm{~kb}$ apart from the Brassica gene BnaA05g33770D and BnaA05g33780D, respectively, which were located on the chromosome A05. The genes associated with these QTLs are F-box family proteins associated with the reduction of flower fertility and reduced number of pod set (Ariizumi et al., 2011), cyclic nucleotide-gated protein that is involved in meiotic division and fruit development (Yang et al., 2006), myb domain protein 57 associated with drought stress tolerance to reduce pod abortion (Baldoni et al., 2015), and adenine nucleotide alpha hydrolases-like superfamily proteins are involved in male sterility and ultimately cause pod abortion (Mok and Mok, 2001).

\section{Material and methods}

\section{Phenotyping}

A total of 84 spring type B. napus accessions were used in this study (Supplementary table S1). The accessions were obtained from Germplasm Resources Information Network (GRIN) (http://www.ars-grin.gov/npgs/searchgrin.html), and were grown in the field at Prosper, North Dakota during summer 2014. The experiment was laid out in a randomized complete block design (RCBD) with 3 replications. Three plants per replication were tagged randomly during flowering time for data collection. During the pod initiation time $\left(1^{\text {st }}\right.$ week to $3^{\text {rd }}$ week of July) the air temperature was about $35^{\circ} \mathrm{C}$ (https://ndawn.ndsu.nodak.edu), which created a natural heat stress for about 20 days (Supplementary table S2). Data on plant height $(\mathrm{cm})$, raceme height $(\mathrm{cm})$, number of pods on the raceme, pod length $(\mathrm{cm})$, and sterile/aborted pod were recorded at the physiological maturity stage of the crop.

\section{Genotyping and association mapping (AM)}

Genomic DNA was extracted from a collection of 366 individuals representing the entire canola diversity available at North Dakota State University (Monika et al. Unpublished) were sequenced using a Genotype-By-Sequencing protocol (Elshire et al. 2011). Briefly, the samples were digested with ApkI enzyme. Illumina GAII sequencer was used to sequence the sample as $100 \mathrm{bp}$ single end reads from size selection of 300-700 bp fragments. Sequence alignments were performed using BWA-mem (Li et al., 2013) and SNP calling using VarScan (Liu et al., 2013). The SNPs obtained at this stage were used for further analysis. FastPHASE (Scheet and Stephens, 2006) was used to estimate the missing alleles. The marker data for these 84 spring type individuals was further cleaned for minor allele frequency of $5 \%$, below which markers were removed. Finally, 37,269 SNPs were subsequently used for this analysis.

\section{Structure analysis, kinship, and model testing}

Population structure was controlled using principal components (PC) that were estimated in TASSEL 5.0 (Bradbury et al., 2007). PCs that account for $25 \%$ and $50 \%$ of cumulative variation were used in association mapping analysis. In addition, a pairwise kinship coefficient matrix (K-matrix) was estimated as the proportion of shared alleles for all pairwise comparisons within the population (Zhao et al., 2007). Six regression models, Naïve, $\mathrm{PC}_{3} \quad(25 \%$ variation), $\mathrm{PC}_{17}$ (50\% variation), kinship, $\mathrm{PC}_{3}+$ kinship, and $\mathrm{PC}_{17}+$ Kinship, were used in this study to identify the marker trait association as well as to select the best models. All the analyses were performed in TASSEL. Among the six models for each trait, a best model was selected based on the smallest Mean Square Difference (MSD) between the observed and expected p-values (Mamidi et al., 2011). Significant markers were identified based on the p-value of a marker within 0.01 and 0.1 percentile tail of 10,000 bootstraps (Mamidi et al., 2014; Gurung et al., 2014; Kertho et al., 2015). Significant markers were selected from the selected best models, and 
Mahhattan plots were constructed using $-\log _{10}$ of $P$-values against chromosome location using qqman package in $\mathrm{R}$ (Turner 2014).

\section{Identification of QTL and candidate genes}

Stepwise regression was implemented in SAS using SAS REG procedure to estimate the combined variation $\left(r^{2}\right)$ explained by all markers and to select the minimum number of markers that can be used for marker assisted selection, and that define a QTL (Mamidi et al. 2014; Gurung et al. 2014). A significant $P$-value of 0.05 was necessary for both marker and model for stepwise inclusion of the marker in REG procedure of SAS 9.3. Further, genes within $100 \mathrm{~kb}$ on either side of the major QTL were used to identify candidate genes. The gene sequences of canola were blasted against the Arabidopsis gene models (TAIR10 database; Berardini et al., 2015) to obtain an annotation for the gene models. Candidate genes were identified on the basis of the physiology and functions of those genes which were previously reported.

\section{Conclusion}

Rapeseed/canola is a heat sensitive crop and can cause significant yield losses at high temperatures. Additionally, the cultivation in U.S. is limited to North Dakota. For improving the crop productivity under heat stress and increasing the cultivation area, there is an urgent need to develop genotypes that are resistant to heat stress. For this, we have included all available spring type germplasm and evaluated in field conditions, where heat stress was observed during the flowering stage. As anticipated, we identified multiple QTL for each of the five agronomic traits. The markers can be used for MAS, while candidate genes within vicinity of QTL can be used for additional functional studies.

\section{Acknowledgements}

The study was supported by the Northern Canola Growers Association under grant number NCGA-2014.

\section{References}

Abdul-Baki AA (1991) Tolerance of tomato cultivars and selected germplasm to heat stress. J Amer Soc Hort Sci.116: 1113-1116.

Ahuja I, de Vos RCH, Bones AM, Hall RD (2010) Plant molecular stress responses face climate change. Trends Plant Sci. 15(12): 664-674.

Angadi SV, Cutforth HW, Miller PR, McConkey BG, Entz MH, Brandt SA, Volkmar KM (2000) Responses of three Brassica species to high temperature stress during reproductive growth. Can J Plant Sci. 80(4): 693-701.

Ariizumi T, Lawrence PK, Steber CM (2011) The role of two F-box proteins, SLEEPY1 and SNEEZY, in Arabidopsis gibberellin signaling. Plant Physiol. 155(2): 765-775

Bak S, Beisson F, Bishop G, Hamberger B, Höfer R, Paquette S, Werck-Reichhart D (2011) Cytochromes P450. Arabidopsis $\quad$ Book 9: e0144.10.1199/tab.0144, doi:10.1199/tab.0144..

Baldoni E, Genga A, Cominelli E (2015) Plant MYB transcription factors: Their role in drought response mechanisms. Int J Mol Sci. 16 : 15811-15851.

Bargaz A, Zaman-Allah M, Farissi M, Lazali M, Drevon JJ, Maougal RT, Carlsson G (2015) Physiological and molecular aspects of tolerance to environmental constraints in grain and forage legumes. Int J Mol Sci. 16: 1897619008.
Barnabás B, Jager K, Feher A (2008) The effect of drought and heat stress on reproductive processes in cereals. Plant Cell Environ. 31: 11-38.

Bellucci A, Torp AM, Bruun S, Magid J, Andersen SB, Rasmussen SK (2015) Association mapping in scandinavian winter wheat for yield, plant height, and traits important for second-generation bioethanol production. Front Plant Sci. 6: 1-12.

Benjamini Y, Yekutieli D (2001) The control of the false discovery rate in multiple testing under depencency. Ann Stat. 29(4): 1165-1188.

Bennetzen JL (2000) Comparative sequence analysis of plant nuclear genomes: microcolinearity and its many exceptions. Plant Cell 12(7): 1021-1029.

Berardini TZ, Reiser L, Li D, Mezheritsky Y, Muller R, Strait E, Huala E (2015) The Arabidopsis information resource: making and mining the "gold standard" annotated reference plant genome. Genesis 53: 474-485.

Bita CE, Gerats T (2013) Plant tolerance to high temperature in a changing environment: scientific fundamentals and production of heat stress-tolerant crops. Front Plant Sci. 4: 273-286.

Bradbury PJ, Zhang Z, Kroon DE, Casstevens TM, Ramdoss Y, Buckler ES (2007) TASSEL: software for association mapping of complex traits in diverse samples. Bioinformatics 23(19): 2633-2635.

Chalhoub B, Denoeud F, Liu S Parkin IAP, Tang H et al. (2014) Early allopolyploid evolution in the post-Neolithic Brassica napus oilseed genome. Science 345: 950-954.

Chrispeels HE, Oettinger H, Janvier N (2000) AtZFP1, encoding Arabidopsis thaliana C2H2 zinc-finger protein 1, is expressed downstream of photomorphogenic activation. Plant Mol Biol. 42(2): 279-290.

Crafts-Brandner SJ, Salvucci ME (2002) Sensitivity of photosynthesis heat stress in a $\mathrm{C} 4$ plant, maize, to heat stress. Plant Physiol. 129(4): 1773-1780.

Craufurd PQ, Bojang M, Wheeler TR, Summerfield RJ (1998) Heat tolerance in cowpea: effect of timing and duration of heat stress. Ann Appl Biol. 133(2): 257-267.

Dat JF, Lopez-Delago H, Foyer CH, Scott IM (1998) Parallel changes in $\mathrm{H}_{2} \mathrm{O}_{2}$ and catalase during thermotolerance induced by salicylic acid or heat acclimation in mustard seedlings. Plant Physiol. 116 1351-1357.

Endo M, Tsuchiya T, Hamada K, Kawamura S, Yano K, Ohshima M, Higashitani A, Watanabe M, KawagishiKobayashi M (2009) High temperatures cause male sterility in rice plants with transcriptional alterations during pollen development. Plant Cell Physiol. 50(11): 1911-1922.

Erickson AN, Markhart AH (2002) Flower developmental stage and organ sensitivity of bell pepper (Capsicum annuum L.) to elevated temperature. Plant Cell Environ. 25(3): 123-130.

Frank G, Pressman E, Ophir R, Althan L, Shaked R, Freedman M, Shen S, Firon N (2009) Transcriptional profiling of maturing tomato (Solanum lycopersicum L.) microspores reveals the involvement of heat shock proteins, ROS scavengers, hormones, and sugars in the heat stress response. J Exp Bot. 60(13): 3891-3908.

Gan Y, Angadi SV, Cutforth H, Potts D, Angadi VV, McDonald CL (2004) Canola and mustard response to short periods of temperature and water stress at different developmental stages. Can J Plant Sci. 84(3): 697-704.

Geiringer H (1944) On the probability theory of linkage in Mendelian heredity. Ann Math Stat. 15: 25-57.

Giorno F, Wolters-arts M, Mariani C, Rieu I (2013) Ensuring reproduction at high temperatures: The heat stress response during anther and pollen development. Plants. 2:489-506. 
Gong M, Li YJ, Chen S Z (1998) Abscisic acid-induced thermotolerance in maize seedlings is mediated by calcium and associated with antioxidant systems. J Plant Physiol. 153:488-496.

Grilli GVG, Braz LT, Lemos EGM (2007) QTL identification for tolerance to fruit set in tomato by fAFLP markers. Crop Breed Appl Biot. 7(3): 234-241.

Guan QJ, Ma HY, Wang ZJ, Wang ZY, Bu QY, Liu SK (2016) A rice LSD1-like-type ZFP gene OsLOL5 enhances saline-alkaline tolerance in transgenic Arabidopsis thaliana, yeast and rice. BMC Genomics 17: 142-152.

Gurung S, Mamidi S, Bonman JM, Xiong M, Brown-Guedira G, Adhikari TB (2014) Genome-wide association study reveals novel quantitative trait loci associated with resistance to multiple leaf spot diseases of spring wheat. PLoS One 9(9). e108179.

Hall JL (2002) Cellular mechanisms for heavy metal detoxification and tolerance. J Exp Bot. 53(366): 1-11.

Hasan M, Friedt W, Pons-Kühnemann J, Freitag NM, Link K, Snowdon RJ (2008) Association of gene-linked SSR markers to seed glucosinolate content in oilseed rape (Brassica napus ssp. napus). Theor Appl Genet. 116(8): 1035-1049.

Hasanuzzaman M, Nahar K, Fujita M (2013) Extreme temperatures, oxidative stress and antioxidant defense in plants, abiotic stress-plant responses and applications in agriculture. In: Vahdati K, Leslie C (ed) Abiotic Stress Plant Responses and Applications in Agriculture, InTech, Rijeka, Croatia. 169-205.

Horváth I, Glatz A, Varvasovszki V, Török Z, Páli T, Balogh G, Kovács E, Nádasdi L, Benkö S, Joó F, Vígh L (1998) Membrane physical state controls the signaling mechanism of the heat shock response in synechocystis PCC 6803: identification of hsp17 as a "fluidity gene". Proc Natl Acad Sci. 95(7): 3513-3518.

Huang X, Zhao Y, Wei X, Li C, Wang A, Zhao Q, Li W, Guo Y, Deng L, Zhu C, Fan D, Lu Y, Weng Q, Liu K, Zhou T, Jing Y, Si L, Dong G, Huang T, Lu T, Feng Q, Qian Q, Li J, Han B (2012) Genome-wide association study of flowering time and grain yield traits in a worldwide collection of rice germplasm. Nat Genet. 44(1): 32-39.

Hudson KA, Hudson ME (2015) A classification of basic helix-loop-helix transcription factors of soybean. Int $\mathbf{J}$ Genomics 1-10.

Hwang E, Song Q, Jia G, Specht JE, Hyten DL, Costa J, Cregan PB (2014) A genome-wide association study of seed protein and oil content in soybean. BMC Genomics 15(1):1-12.

Ivashuta S, Naumkina M, Gau M, Uchiyama K, Isobe S, Mizukami Y, Shimamoto Y (2002) Genotype-dependent transcriptional activation of novel repetitive elements during cold acclimation of alfalfa (Medicago sativa). Plant J. 31(5): 615-627.

Jin H, Xu G, Meng Q, Huang F, Yu D (2013) GmNAC5, a NAC transcription factor, is a transient response regulator induced by abiotic stress in soybean. The scientific world J. $1-5$.

Kang J, Park J, Choi H, Burla B, Kretzschmar T, Lee Y (2011) Plant ABC transporters. Am Soc Plant Biol. 1-25.

Kaya H, Ichi S. K, Ichiro T. K, Iwabuchi M, Stillman B, Araki T (2001) FASCIATA genes for chromatin assembly factor-1 in Arabidopsis maintain the cellular organization of apical meristems. Cell 104(1): 131-142.

Kelish A, El F, Zhao W, Heller J, Durner J, Winkler B, Behrendt H, Traidl-hoffmann C, Horres R, Pfeifer M, Frank U, Ernst D (2014) Ragweed (Ambrosia artemisiifolia) pollen allergenicity: SuperSAGE transcriptomic analysis upon elevated $\mathrm{CO}_{2}$ and drought stress. BMC Plant Biol. 14(1): 1-16.

Kertho A, Mamidi S, Michael JB, McClean PE, Maricelis A (2015) Genome-wide association mapping for resistance to leaf and stripe rust in winter-habit hexaploid wheat landraces. PLoS ONE 10 (6): e0129580.

Kim SY, Hong CB (2001) Heat shock stress causes stagespecific male sterility in Arabidopsis thaliana. J Plant Res. 114: 301-307.

Konsens I, Ofir M, Kigel J (1991) The effect of temperature on the production and abscission of flowers and pods in snap bean (Phaseolus vulgaris L.). Ann Bot. 67: 391-399.

Leisner CP, Ming R, Ainsworth EA (2014) Distinct transcriptional profiles of ozone stress in soybean (Glycine max) flowers and pods. BMC Plant Biol. 14: 1-13.

Levy A, Rabinowitch HD, Kedar N (1978) Morphological and physiological characters affecting flower drop and fruit set of tomatoes at high temperatures. Euphytica 27: 211218.

Lewontin R, Kojina K (1960) The evolutionary dynamics of complex polymorphisms. Evolution 14: 458-472.

Li H, Peng Z, Yang X, Wang W, Fu J, Wang J, Han Y, Chai Y, Guo T, Yang N, Liu J, Warburton ML, Cheng Y, Hao X, Zhang P, Zhao J, Liu Y, Wang G, Li J, Yan J (2013) Genome-wide association study dissects the genetic architecture of oil biosynthesis in maize kernels. Nat Genet. 45(1): 43-50.

Li N, Shi J, Wang X, Liu G, Wang H (2014) A combined linkage and regional association mapping validation and fine mapping of two major pleiotropic QTLs for seed weight and silique length in rapeseed (Brassica napus L.). BMC Plant Biol. 14(1): 114-127.

Li S, Fu Q, Chen L, Huang W, Yu D (2011) Arabidopsis thaliana WRKY25, WRKY26, and WRKY33 coordinate induction of plant thermotolerance. Planta 233: 1237-1252.

Li S, Xie Z, Hu C, Zhang J (2016) A review of auxin response factors ( ARFs ) in plants. Front Plant Sci. 7: 1-7.

Lin YC, Li W, Chen H, Li Q, Sun YH, Shi R, et al. (2014) A simple improved-throughput xylem protoplast system for studying wood formation. Nat Protoc. 9:2194-2205.

Lin Y, Lin L, Lai R, Liu W, Chen Y, Zhang Z, Xuhan X (2015) Cleavage leads to the production of embryogenesis in Dimocarpus longan Lour. Front Plant Sci. 6: 1-15.

Liu L, Qu C, Wittkop B, Yi B, Xiao Y, He Y, Snowdon RJ, Li J (2013) A high-density SNP map for accurate mapping of seed fibre QTL in Brassica napus. PLoS ONE 8(12): 19.

Lo SF, Yang SY, Chen KT, Hsing YL, Zeevaart JAD, Chen LJ, Yu SM (2008) A novel class of gibberellin 2-oxidases control semidwarfism, tillering, and root development in rice. Plant Cell 20:2603-2618.

Lucas MR, Ehlers JD, Roberts PA, Close TJ (2013) Markers for breeding heat-tolerant cowpea. Mol Breeding 31:529 536.

Ma Z, Leng Y, Chen G, Zhou P, Ye D, Chen L (2005) The thermosensitive male sterile 1 interacts with the BiPs via DnaJ domain and stimulates their ATPase enzyme activities in Arabidopsis. PLoS ONE 10(7): e0132500.

Maeda H, Song W, Sage T, Dellapenna D (2014) Role of callose synthases in transfer cell wall development in tocopherol deficient Arabidopsis mutants. Front Plant Sci. 5: $1-15$.

Maestri E, Klueva N, Perrotta C, Gulli M, Nguyen HT, Marmiroli N (2002) Molecular genetics of heat tolerance and heat shock proteins in cereals. Plant Mol Biol. 48(5-6): 667-681.

Mamidi S, Chikara S, Goos RJ, Hyten DL, Annam D, 
Moghaddam SM, Lee RK, Cregan PB, McClean PE (2011) Genome-wide association analysis identifies candidate genes associated with iron deficiency chlorosis in soybean. The Plant Genome 4(3): 154.

Mamidi S, Lee RK, Goos JR, McClean PE (2014) Genomewide association studies identifies seven major regions responsible for iron deficiency chlorosis in soybean (Glycine max). PLoS ONE 9(9).e107469.

Matschi S, Werner S, Schulze WX, Legen J, Hilger HH, Romeis T (2013) Function of calcium-dependent protein kinase CPK28 of Arabidopsis thaliana in plant stem elongation and vascular development. Plant J. 73: 883-896.

Mazzucotelli E, Belloni S, Marone D, De Leonardis AM, Guerra D, Di Fonzo N (2006) The E3 ubiquitin ligase gene family in plants : regulation by degradation. Curr Genomics 7: 509-522

Mittler R, Blumwald E (2010) Genetic engineering for modern agriculture: challenges and perspectives. Annu Rev Plant Biol. 61: 443-462.

Mok DWS, Mok MC (2001) Cytokinin metabolism and action. Plant Mol Biol. 52: 89-118.

Monika M, Mamidi S, McClean PE, Rahman M (Unpublished). Low level of linkage disequilibrium and population structure in a core collection of Brassica napus discovered using SNPs derived from GBS (unpublished).

Morrison MJ (1993) Heat stress during reproduction in summer rape. Can J Bot. 71(2): 303-308.

Muguet, B, Hooghe PD, Bataillé M, Larré C, Kim T, Trouverie J, Avice J, Etienne P, Dürr C (2015) Heat stress during seed filling interferes with sulfur restriction on grain composition and seed germination in oilseed rape ( Brassica napus L.). Front Plant Sci. 6: 1-12.

Nuttall WF, Moulin AP, Townley-Smith LJ (1992) Yield response of canola to nitrogen, phosphorus, precipitation, and temperature. Agron J. 84(5): 765-768.

Ortiz R, Braun HJ, Crossa J, Crouch JH, Davenport G, Dixon $J$ et al. (2008) Wheat genetic resources enhancement by the International Maize and Wheat Improvement Center (CIMMYT). Genet Resour Crop Evol. 55(7): 1095-1140.

Oshino T, Abiko M, Saito R, Ichiishi E, Endo M, KawagishiKobayashi M, Higashitani A (2007) Premature progression of anther early developmental programs accompanied by comprehensive alterations in transcription during hightemperature injury in barley plants. Mol Genet Genomics 278(1): 31-42.

Park HJ, Jung WY, Lee SS, Song JH, Kwon SY, Kim H, Kim C, Ahn JC, Cho HS (2013) Use of heat stress responsive gene expression levels for early selection of heat tolerant cabbage (Brassica oleracea L.). Int J Mol Sci. 14: 11871-11894.

Price AL, Zaitlen NA, Reich D, Patterson N (2010) New approaches to population stratification in genome-wide association studies. Nat Rev Genet. 11:459-463.

Rao GU, Jain A, Shivanna KT (1992) Effects of high temperature stress on Brassica pollen: viability, germination and ability to set fruits and seeds. Ann Bot. 69:193-198.

Radchuk R, Radchuk V, Weschke W, Borisjuk L, Weber H (2006) Repressing the expression of the sucrose nonfermenting-1-related protein kinase gene in pea embryo causes pleiotropic defects of maturation similar to an abscisic acid intensive phenotype. Plant Physiol. 140: 263278.

Ranty B, Aldon D, Philippe J (2006) Plant calmodulins and calmodulin-related proteins. Plant Signal Behav. 1(3): 96104.

Raymer PL (2002) Canola: An emerging oilseed crop. In:
Janick J, Whipkey A (ed) Trends in new crops and new uses, ASHS Press, Alexandria, VA. 122-126.

Reddy KR, Hodges HF, Reddy VR (1992) Temperature effects on cotton fruit retention. Agron J. 84: 26-30.

Reynolds MP, Pierre CS, Saad ASI, Vargas M, Condon AG (2007) Evaluating potential genetic gains in wheat associated with stress-adaptive trait expression in elite genetic resources under drought and heat stress. Crop Sci. 47:172-189.

Risch NJ (2000) Searching for genetic determination for the new millennium. Nature 405:847-856.

Rylski I (1986) Pepper (Capsicum). In: Monselise SP (ed) Handbook of fruit set and development, CRC Press, Boca Raton, FL, USA. 341-354.

Sakai H, Hua J, Chen G, Chang C, Anthony AEMM, Bleecker B (1998) ETR2 is an ETR1-like gene involved in ethylene signaling in Arabidopsis. Plant Biol. 95: 5812 5817.

Samuel MA, Chong YT, Haasen KE, Aldea-brydges MG, Stone SL, Goring DR (2009) Cellular pathways regulating responses to compatible and self-incompatible pollen in Brassica and Arabidopsis stigmas intersect at Exo70A1, a putative component of the exocyst complex. Plant Cell 21: $2655-2671$.

Sangwan V, Orvar BL, Beyerly J, Hirt H, Dhindsa RS (2002) Opposite changes in membrane fluidity mimic cold and heat stress activation of distinct plant MAP kinase pathways. Plant J. 31: 629-638.

Savchenko GE, Klyuchareva EA, Abramchik LM, Serdyuchenko EV (2002) Effect of periodic heat shock on the inner membrane system of etioplasts. Russ J Plant Physiol. 49(3): 349-359.

Scheet P, Stephens M (2006) A fast and flexible statistical model for large-scale population genotype data: applications to inferring missing genotypes and haplotypic phase. Am J Hum Genet. 78(4): 629-644.

Shao L, Shu Z, Sun SL, Peng CL, Wang XJ, Lin ZF (2007) Antioxidlation of anthocyanins in photosynthesis under high temperature stress. J Integr Plant Biol. 49(9): 13411351.

Sharma KD, Nayyar H (2014) Cold stress alters transcription in meiotic anthers of cold tolerant chickpea (Cicer arietinum L.). BMC Res Notes 7: 717-729.

Sharma M, Pandey GK (2016) Expansion and Function of repeat domain proteins during stress and development in plants. Front Plant Sci. 6: 1-23.

Sinha AK, Jaggi M, Raghuram B, Tuteja N (2011) Mitogenactivated protein kinase signaling in plants under abiotic stress. Plant Signal Behav. 6(2): 196-203.

Song X, Li Y, Hou X (2013) Genome-wide analysis of the AP2 / ERF transcription factor superfamily in Chinese cabbage (Brassica rapa ssp. pekinensis). BMC Genomics 14: 573-587.

Steward N, Ito M, Yamaguchi Y, Koizumi N, Sano H (2002) Periodic DNA methylation in maize nucleosomes and demethylation by environmental stress. J Biol Chem. 277(40): 37741-37746.

Trick M, Long Y, Meng J, Bancroft I (2009) Single nucleotide polymorphism (SNP) discovery in the polyploid Brassica napus using solexa transcriptome sequencing. Plant Biotechnol J. 7(4): 334-346.

Turner SD (2014) qqman: an $\mathrm{R}$ package for visualizing GWAS results using Q-Q and manhattan plots. DOI: $10.1101 / 005165$.

U N (1935) Genome analysis in Brassica with special reference to the experimental formation of $B$. napus and peculiar mode of fertilization. Japan J Bot. 7: 389-452. 
Van de poel B, Van Der Straeten D (2014) 1aminocyclopropane-1-carboxylic acid ( ACC) in plants : more than just the precursor of ethylene. Front Plant Sci. 5: $1-11$.

Vierling E (1991) The roles of heat shock proteins in plants. Annu Rev Plant Physiology Plant Mol Biol. 42(1): 579620.

Volkov RA, Panchuk II, Mullineaux PM, Schöffl F (2006) Heat stress-induced $\mathrm{H}_{2} \mathrm{O}_{2}$ is required for effective expression of heat shock genes in Arabidopsis. Plant Mol Biol. 61(4-5): 733-746.

Vollenweider P, Günthardt-Goerg MS (2005) Diagnosis of abiotic and biotic stress factors using the visible symptoms in foliage. Environ Pollut. 137(3): 455-465.

Waraich EA, Ahmad R, Halim A, Aziz T (2012) Alleviation of temperature stress by nutrient management in crop plants: a review. J soil Sci plant Nutr. 12(2): 221-244.

Wery J, Tardieu F (1997) Heat stress-induced abortion of buds and flowers in pea: is sensitivity linked to organ age or to relations between reproductive organs? Ann Bot. 80: 159-168.

Wilson ZA, Song J, Taylor B, Yang C (2011) The final splitthe regulation of anther dehiscence. J Exp Bot. 1-17.

Wu W, Cheng Z, Liu M, Yang X, Qiu D (2014) C3HC4Type RING finger protein NbZFP1 is involved in growth and fruit development in Nicotiana benthamiana. PLoS ONE. 9(6):e99352

Xiao D, Wang H, Basnet RK, Zhao J, Lin K, Hou X, Bonnema G (2014) Genetic dissection of leaf development in Brassica rapa using a genetical genomics approach. Plant Physiol. 164(3): 1309-1325.

Yamamoto Y, Aminaka R, Yoshioka M, Khatoon M, Komayama K, Takenaka D, Yamashita A, Nijo N, Inagawa K, Morita N, Sasaki T (2008) Quality control of photosystem II: impact of light and heat stresses. Photosynth Res. 98:589-608.

Yang A, Li Y, Xu Y, Zhang W (2013) A receptor-like protein $\mathrm{RMC}$ is involved in regulation of iron acquisition in rice. $\mathrm{J}$ Exp Bot. 64(16): 5009-5020.

Yang K, Xia C, Liu X, Dou X, Wang W, Chen L, Zhang X, Xie L (2009) A mutation in thermosensitive male sterile 1, encoding a heat shock protein with DnaJ and PDI domains, leads to thermosensitive gametophytic male sterility in Arabidopsis. The Plant Journal 57: 870-882.

Yang TJ, Kim JS, Kwon SJ, Lim KB, Choi BS, Kim JA, Jin M, Park JY, Lim MH, Kim HI, Lim YP, Kang JJ, Hong JH, Kim CB, Bhak J, Bancroft I, Park BS (2006) Sequencelevel analysis of the diploidization process in the triplicated flowering locus $\mathrm{C}$ region of Brassica rapa. Plant Cell
18(6): 1339-1347.

Yasin MA, Nazia A, Hussain M (2006) Indole acetic acid (IAA) induced changes in growth, relative water contents and gas exchange attributes of barley (Hordeum vulgare L.) grown under water stress conditions. Plant Growth Regul. 50(1):85-90

Ye C, Tenorio FA, Argayoso MA, Laza MA, Koh HJ, Redoña ED, Jagadish KSV, Gregorio GB (2012) Identifying and confirming quantitative trait loci associated with heat tolerance at flowering stage in different rice populations. BMC Genet. 16 (41): 1-10.

Yu J, Pressoir G, Briggs WH, Vroh Bi I, Yamasaki M, Doebley JF, McMullen MD, Gaut BS, Nielsen DM, Holland JB, Kresovich S, Buckler ES (2006) A unified mixed-model method for association mapping that accounts for multiple levels of relatedness. Nat Genet. 38(2): 203 208

Yu H, Xu Y, Tan EL, Kumar PP (2002) AGAMOUS-LIKE 24, a dosage-dependent mediator of the flowering signals. PNAS. 99(25):16336-16341.

Zang L, Zheng T, Chu Y, Ding C, Zhang W, Lara MV (2015) Genome-wide analysis of the fasciclin-like arabinogalactan protein gene family reveals differential expression patterns, localization, and salt stress response in populus. Front Plant Sci. 6:1-16.

Zegeye H, Rasheed A, Makdis F, Badebo A, Ogbonnaya FC (2014) Genome-wide association mapping for seedling and adult plant resistance to stripe rust in synthetic hexaploid wheat. PLoS ONE 9(8): e105593.

Zhang J, Jia W, Yang J, Ismail AM (2006) Role of ABA in integrating plant responses to drought and salt stresses. Field Crops Res. 97: 111-119.

Zhang D, Hua Y, Wang X, Zhao H, Shi L, Xu F (2014) A high-density genetic map identifies a novel major QTL for boron efficiency in oilseed rape (Brassica napus L.). PLoS ONE 9(11). e112089.

Zhao K, Aranzana MJ, Kim S, Lister C, Shindo C, Tang C, Toomajian C, Zheng H, Dean C, Marjoram P, Nordborg M (2007) An Arabidopsis example of association mapping in structured samples. PLoS Genet. 3(1): 71-82.

Zhao C, Zhao S, Hou L, Xia H, Wang J, Li C, Li A, Li T, Zhang X, Wang X (2015) Proteomics analysis reveals differentially activated pathways that operate in peanut gynophores at different developmental stages. BMC Plant Biol. 15: 1-12.

Zhu C, Gore M, Buckler ES, Yu J (2008) Status and prospects of association mapping in plants. Plant Genome 1: 5-20. 